Article

\title{
Livestock Farming at the Expense of Water Resources? The Water-Energy-Food Nexus in Regions with Intensive Livestock Farming
}

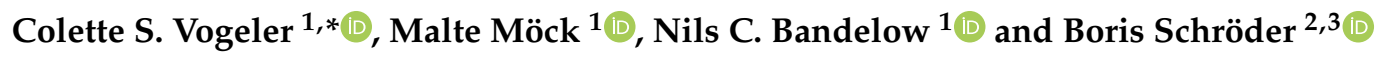 \\ 1 Comparative Politics and Public Policy, TU Braunschweig, 38106 Braunschweig, Germany; \\ m.moeck@tu-braunschweig.de (M.M.); nils.bandelow@tu-braunschweig.de (N.C.B.) \\ 2 Landscape Ecology and Environmental Systems Analysis, Institute of Geoecology, Technische Universität \\ Braunschweig, 38106 Braunschweig, Germany; boris.schroeder@tu-braunschweig.de \\ 3 Berlin-Brandenburg Institute of Advanced Biodiversity Research (BBIB), 14195 Berlin, Germany \\ * Correspondence: colette.vogeler@tu-braunschweig.de
}

Received: 9 September 2019; Accepted: 3 November 2019; Published: 7 November 2019

\begin{abstract}
Policymaking in the water-energy-food nexus is characterized by complex ecological, social, and economic interdependencies. Nexus research assumes these interactions to be overseen in the respective resource governance resulting in sectoral perspectives contributing to unsustainable outcomes. In Germany, the political priority given to the formation of an internationally competitive livestock sector by means of intensification, specialization and regional concentration has exerted sustained pressure on water and soil resources. The expansion of bioenergy plants promoted by the renewable energy act has exacerbated the situation. Despite the persistency of the ecological challenges, German policymakers only reacted when the European Commission referred Germany to the European Court of Justice. Current policy efforts to tackle the ecological problems are now provoking disruptions in the agrarian sector in regions with high nitrate concentrations in water resources. By combining the social-ecological systems framework with hypotheses derived from nexus research, we explore the interactions between food, water and energy systems and aim at understanding the unsustainable outcomes. We argue that the non-consideration of the complex interdependencies between the agricultural, the water and the energy system in policymaking and the divergence of policy goals constitute a major cause of unsustainable governance.
\end{abstract}

Keywords: water-energy-food nexus; social-ecological systems framework; water pollution; agricultural policy; livestock farming

\section{Introduction}

In June 2018, Germany was sentenced by the Court of Justice of the European Union for failure to combat water pollution in groundwater and surface water caused by nitrates [1]. The judgment can be interpreted as a failure of German water governance and a turning point within the water-energy-food nexus in selected regions in Germany. The development of an internationally competitive livestock sector by means of intensification, specialization and regional concentration, especially in North-western Germany, has exerted sustained pressure on water and soil resources [2]. The expansion of bioenergy plants promoted by the government in exactly the same regions has exacerbated the situation by adding to the competition for land and by creating fermentation residues [3]. The combination of agrarian and bioenergy producing activities thereby culminated in an ecologically unsustainable use of water resources. The pressure that food and energy production exerted on the water subsystem was not identified as a policy problem by policymakers in the agricultural and the energy policy subsystems. Despite the persistency of the problem, the German government only took harsh political measures 
when the European Commission referred Germany to the Court of Justice in 2016 [4]. With the new fertilizer ordinance in 2017 [5], the federal government passed a controversial policy that is currently provoking disruptions in the agrarian sector in regions with high nitrate concentrations in water resources. It is unclear if the new policy will lead to improvements in water quality [6], in 2019 the European Commission has called on Germany to further tighten the regulations passed in 2017 [7]. Our research reveals that the outcome will contribute to structural transformations in the livestock sector and thereby have probably unintended social and economic consequences. By studying the region in Germany with the highest livestock density and the worsening of groundwater relating thereto [8], we aim at a better understanding of these developments and the apparently unsustainable governance of water and soil resources. Two theoretical perspectives are helpful for achieving this. On the one hand, research on the water-energy-food nexus emphasizes the sectoral characteristics of decision-making in natural resource governance $[9,10]$. Therefore, a nexus problem emerges if governance of one resource neglects its consequences on interconnected others. Integrated water resource management picks up these challenges with the aim to promote sustainable management across sectors. Scholars of public policy are engaging in the design of new policy instruments that encourage collaboration not only across sectors but as well across countries and across scales [11]. On the other hand, the social-ecological systems framework (SES) assumes that different ecological systems require specific governance arrangements, which are customized according to the ecological as well as the social dynamics of the system and that are sufficiently flexible in adapting to system changes.

Applying the SES [12-14], we ask first how the adverse ecological outcome came about and secondly how the SES can add to the understanding of the multifaceted interplay in the water-energy-food system in Germany. The application of the social-ecological systems framework allows us to systematically explore the resource systems in the region and the interdependencies between the water, the energy and the food system. We argue that a major challenge to the sustainable management of food, energy and water resources is that policymaking is traditionally divided between the policy subsystems and that policy goals diverge. Taking up hypotheses from nexus research we show that policymaking is still relatively unconnected between food, water and energy policy [15-17]. Each of these policy fields has different goals and priorities, which do not sufficiently consider the influences on the respective other subsystems $[18,19]$. This leads to adverse outcomes and prevents a sustainable management of resources. In our case study, this divergence of policy goals has contributed to policies that prioritize agricultural goals over ecological goals. Even recent policies as the new fertilizer ordinance of 2017 are designed without considering social-ecological system fit. We argue that this is partly a consequence of the division of the policy subsystems and the political priority given to the food system in Germany.

Methodologically, we rely on case study methods including fieldwork in the region under analysis and the combination of several data sources such as policy documents, agricultural and economic statistics as well as scientific reports, e.g., regarding water pollution. Our case study comprises two counties in Germany (Cloppenburg and Vechta) with outstanding surplus nitrate levels in water resources. In addition, these regions are hubs of German livestock production, in particular pig and poultry production [2].

The findings on the one hand point towards a more holistic consideration of ecological and socio-economic variables in German policymaking and an improved adjustment of policies between the subsystems water, energy and food. By combining the SES with nexus research, we contribute to its further elaboration. Applying the SES in Germany, we furthermore discuss specifics of the German political system that should be given consideration in future adaptations of the SES. Particularly outstanding is the traditional practice of top-down and centralized policymaking that limits the leeway of local policy solutions. In the fields of environmental and agricultural policymaking even the national range is highly restricted by the dense regulations stemming from the European Union. 


\section{A Social-Ecological Systems Framework Perspective on German Water Governance}

The social-ecological systems framework was introduced by Elinor Ostrom in addition to the institutional analysis and development (IAD) framework [20] with the aim to better address ecological variables within institutional analysis [12,21-23]. The SES perspective assumes that different ecological systems require specific governance arrangements that are customized according to the ecological as well as the social system dynamics and that are sufficiently flexible in adapting to system changes.

We selected this framework for the empirical analysis because it allows for a systematic analysis of the dynamics of social-ecological systems. The SES enables us to identify the dynamics of the social-ecological systems, which requires addressing ecological, social, economic as well as political variables. Secondly, by applying the SES we can uncover causes of unsustainable resource use and, from a social science perspective, governance failures and pathways towards sustainable water governance.

Its specific strength lies in the equal consideration of ecological and social variables. The SES assumptions have been developed based on a large number of empirical case studies in different countries with the aim to understand human-environment interactions [24]. The aim of SES scholars is to identify the causes of unsustainable resource use and derive implications and recommendations for the sustainable management of resources. It has proven particularly relevant in the context of common-pool resources such as water governance [25]. Regarding the governance of social-ecological systems, the perspective of the framework advocates for an integral consideration of the ecological and the socio-economic context in policy development [14,26]. Policies should aim at matching with the dynamic nature of the ecological and the social contexts [13], i.e., reaching the social-ecological system fit. It is assumed that this matching of ecological and institutional scales enhances sustainability of governance [17,24].

To this aim, the SES coequally integrates ecological, economic, social and political variables and is therefore especially suited for interdisciplinary collaboration. An SES consists of four subsystems that affect and interact with each other: the resource system (RS), the governance system (GS), the resource units (RU) and the users (U). These subsystems are shaped by interactions (I) that lead to specific social and ecologic outcomes $(\mathrm{O})$. In addition, each SES is linked to social, economic and political settings (S) as well as to related ecosystems (ECO). The framework provides a collection of first-, second- and third-tier variables for each subsystem; in sum it proposes more than 50 variables [12]. These variables are designed to explore the dynamic interactions within an SES. Notwithstanding, not all second- and third-tier variables are relevant for each case; to apply the framework, a prioritization and selection of variables is necessary [23]. The selection among others depends on the research question [12]. This great flexibility is likewise a strength and weakness of the SES framework. On the one hand, it is open to be applied to different systems, on the other hand existing applications often lack consistency. The missing comparability of case studies can partly be attributed to the fact that the SES is a relatively new, and therefore still evolving framework [26]. In addition, until today the majority of SES studies were conceptual and not data-driven and the framework has been applied rather inconsistently [24].

For the field of agriculture and for the case of Germany, SES studies are scarce $[23,26]$. The particularities of the German political system may require an adaptation of the framework. In particular, this includes the tradition of top-down policymaking, the central role of political parties in transferring interests into policymaking and corporatist interest representation [27]. Furthermore, the integration of Germany in the European Union presents a specific challenge for national policymaking, as environmental and agrarian policy are among the most Europeanized policy fields $[28,29]$.

Most SES studies focus on a single resource and analyze the use and the governance of this resource with the aim to uncover mechanisms to enhance sustainability within the specific resource system [23]. In our case, however, we deal with at least two resources with significantly diverging characteristics responsible for trade-offs: the first resource is the production of food that is dominated by market mechanisms. The primary goal of users within this resource system is the production of 
food by private actors within a competitive market [30]. The second resource is water in the form of groundwater and surface water, which is a common-pool resource and influenced by the food system in manifold ways [16]. The integration of water-related policies in other policy fields remains a challenge and in many cases results in the pollution or overharvesting of water resources [19,31,32]. Though integrated water resource management is gaining scholarly and political relevance, there are still important deficiencies when it comes to the concrete implementation [11].

The interplay between the resource systems "water", "energy" and "food" is in the middle of nexus research. Nexus research aims at linking ideas and actions of stakeholders from different systems to foster the sustainable development of these [15]. Recently, nexus research has been introduced to the IAD discussion [33]. In the SES framework and its applications, nexus research has not been given substantial attention yet, since most SES studies are limited to only one resource. For the sustainable governance of interacting resource systems, Klümper and Theesfeld therefore propose a new second-tier variable, which they call "governance nexus" [34].

Taking up these research lines, we argue that the two overlapping resource systems-food and water-follow their own logic. Despite their mutual dependence, political and economic actors in both systems in Germany operate rather independently from each other. This is most evident in the formal separation of ministries in Germany, i.e., the Ministry of Agriculture and the Ministry of Environment. The latter holds responsibility for water, the former for food governance. Following nexus research, we firstly assume that the interplay of the resources water and food is insufficiently considered in the governance of the two systems. Secondly, we argue that the different characteristics of the two resource systems present a major challenge for sustainability in the nexus. The food system in Germany is dominated by private actors and characterized by competition. Water, on the contrary, is a common-pool resource, which in Germany is managed by public water boards and is independent of market mechanisms.

Secondly, we expect that the different characteristics and use of the resources food and water result in highly diverging goals of actors within each system. The strategies of actors in the food system can be explained by economic concerns, whilst actors in the water system are preoccupied with the sustainable use of the common-pool resource. We assume that actors in each system are primarily concerned with their respective resource and therefore do not sufficiently consider the needs and characteristics of the other resource which leads to adverse outcomes, in particular the overharvesting of resources. By applying the SES to the analysis of the interactions in both systems, our study contributes to the understanding of the unsustainable management of a social-ecological system in a highly intensified agrarian region in Germany.

\section{Selection of SES Variables for the Analysis of the Water-Energy-Food Nexus in the Study Region Cloppenburg-Vechta and Data Collection}

The first challenge in applying the framework is the geographical delimitation of the social-ecological system, because ecological and social systems may exhibit different boundaries, e.g., aquifers versus areas of water management. We opt for a definition of borders along the governance dimension and accordingly along the administrative borders of the districts Cloppenburg and Vechta (see Figure 1). The orientation along administrative borders is reflected in both the food and the water system in the region. In the food system, the representatives of the local farmers' associations are organized along administrative borders with one association for the region of Cloppenburg (KLV Cloppenburg) and another association for the region of Vechta (KLV Vechta). In the regional water board OOWV (Oldenburgisch-Ostfriesischer Wasserverband), management structures are likewise organized along administrative borders [35]. The total area of the district Vechta is around 800 square kilometers, the area of the district Cloppenburg around 1400 square kilometers. Taken together, the two districts are inhabited by a population of around 300,000 inhabitants [36]. The selected area thereby represents a rather large area compared to other SES studies, which are often limited to the local scale. Nevertheless, the specific strength of the SES - the co-equal consideration of ecological, social, 
economic and political variables-provides systematic guidance to the understanding of the dynamics between and within food and water systems in the selected area.

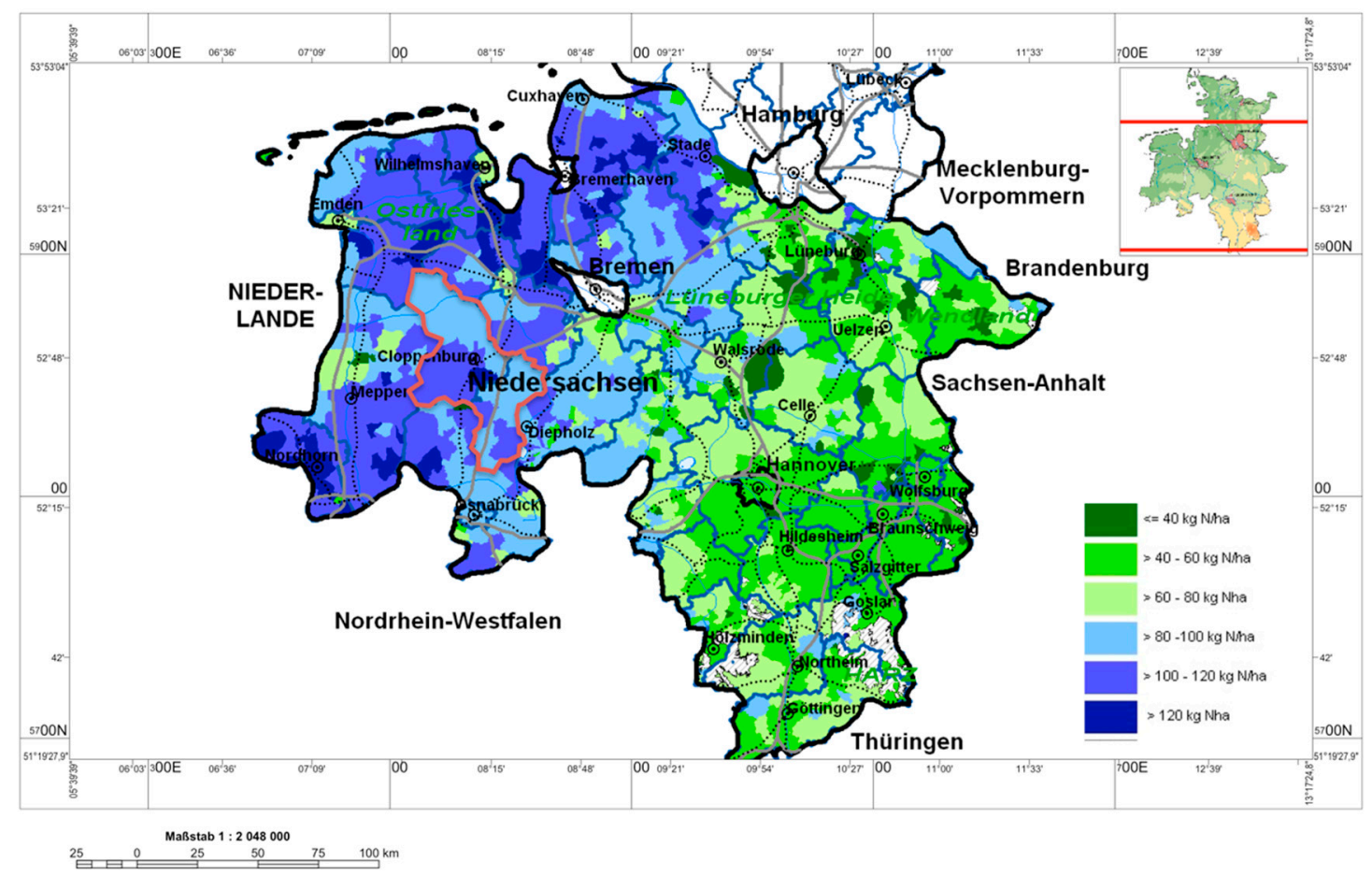

Figure 1. Case study regions Cloppenburg and Vechta and nitrogen levels. Nitrogen levels in Lower Saxony, marked in red are the case study regions Cloppenburg and Vechta (source: NIBIS®Kartenserver (2014): Stickstoff-Flächenbilanzsaldo auf Gemeindeebene, Landesamt für Bergbau, Energie und Geologie (LBEG), Hannover; study region marked by the authors).

The second challenge in applying the SES is the selection of variables from the originally proposed set [12]. The explicit focus of our analysis is the fit of the governance system with the ecological, social and economic characteristics of the system. Variables subsumed in the SES categories resource systems (RS), resource units (RU) and users (U) instruct the analysis of these characteristics. The SES assumes that the characteristics of the specific resource system and the attributes of the resource units influence the interactions and the interdependencies between the actors within the SES [25]. Accordingly, in the first step the researcher must generate knowledge about RS, RU and U. Consequently, the governance systems (GS), the interactions (I) and the outcomes (O) can be analyzed. The selection of SES variables depends on the respective case under analysis. SES scholars select the relevant variables based on their knowledge of the case, the academic literature and the fieldwork. Commonly applied methods to gather data are expert interviews or surveys with actors from the system under analysis [24].

We selected the variables relevant for our case in a two-stage process: At the beginning of our research we identified a set of variables based on the reading of existing documents, government data and scientific research on the food system and the water system in the region. The investigation included an online document research on the case. We looked at legislation and other policies, agricultural and economic statistics as well as scientific reports on water usage and pollution in the region. Based on the obtained information, we chose a preliminary set of variables and integrated these variables in the design of a key questionnaire for our fieldwork. The questionnaire was developed for interviews of experts in the districts Cloppenburg and Vechta. Fieldwork was conducted in May and June of 2018. Following the collection of empirical material, we adapted the selection of SES variables according to the insights from the interviews. An overview of the selected variables and the operationalization of the variables can be found in the annex. As our research interest focuses on the interaction between groundwater resources and food production, the first variable we selected from RS is the second-tier 
variable RS1 sector. Initially, we thought of two sectors: food and water. However, during the interviews a third sector emerged, which was energy and, in particular, the building of biogas plants. The interdependencies are described in the ensuing empirical analysis. Secondly, given the focus of farmers on livestock farming in the study region, we decided to include RS4 human-constructed facilities. Here, stables are relevant as well as biogas plants that were installed in the region as a consequence of the political promotion of renewable energies in Germany. The negative ecological concomitants of both, the construction of stables and the building of biogas plants, were stressed by several interviewees.

With respect to RU, we selected three second-tier variables for the analysis. Given the interdependencies between the two sectors water and food, we argue that the mobility of the resource units (RU1) is an important difference. Whereas the common-pool resource groundwater is highly mobile, privately owned livestock is rather immobile given the large amortization periods of stables which make them comparatively place-bounded and severely restricts the scope of action for farmers. This fact was emphasized by the farmers we interviewed. Furthermore, we selected the variable interaction among resource units (RU3) for the analysis. This decision is grounded in the nexus hypotheses. Thirdly, given the importance of livestock farming in the region under analysis, we decided to include RU4 (economic value) into the analysis.

With respect to $U$, we selected the second-tier variables history of use (U3), and importance of resource (U8). The selection is grounded on the high dependency of the region on livestock farmers and the evolving path dependencies in this agricultural sector.

Regarding GS, we firstly decided to look at the government organizations (GS1). Agricultural policy in Germany is highly Europeanized, which is why a multilevel analysis is needed. Water policy instead is allocated in the environmental policy subsystem and is far more regionalized. Several interviewees raised the institutional challenges resulting from these organizational structures. The multilevel character of the governance system makes it indispensable to look at regulations targeting the social-ecological system, which is why we included constitutional choice rules (GS7). There was a consensus among the interviewees that the fertilizer ordinance, which forms part of the implementation of the EU Water Framework Directive (WFD), has had a decisive impact on food and energy producing activities in the region. In connection to this, the control and enforcement of the regulations are important. We therefore thirdly included the variable monitoring and sanctioning processes (GS8).

In the field of resource governance, we are especially interested in self-organizing activities (I7). Self-organization is recognized as an important variable for the sustainable use of resources by SES scholars [12]. In addition, given the historically strong position of farmers' associations in Germany (in particular within the governing party $\mathrm{CDU} / \mathrm{CSU}$ ) we decided to include the variable lobbying activities (I6) to our case study. The final list of the selected SES variables is depicted in Table 1.

With the expert interviews we chose a qualitative approach to the research field [37]. Compared with more standardized methods the openness of this qualitative research design presents a major advantage for understanding the ideas and motivations of the actors within the policy field. A common critique regarding semi-structured expert interviews is the danger of overestimating individual opinions and interpretations regarding the issue under analysis. This subjective nature at the same time is a substantial advantage of the method. The different frames of the actors are essential in understanding the behavior and interactions within the subsystem under analysis. In addition to the interviews, the collected data were contrasted with existing documents and the responses of the other interview partners to get the full picture. In selecting the interview partners, we aimed at achieving a balance of actors from all relevant stakeholder groups involved in the food and water systems in the region. Among our interview partners were representatives from the local farmers' associations, the upward and downward food production chain, the water board, the political and administrative sector and a private sector initiative founded around the challenges of local agriculture and water management. The interviews were conducted personally by the authors and recorded. A list of the interviews is found in Table 2. We have numbered the interviews from one to seven to cite them in the 
ensuing sections. To ensure the anonymity of the interview partners the order of the interviews in the table does not correspond to numbers given in the text but follows an internal order. The empirically generated material provides an important foundation for the analysis of the social-ecological system.

Table 1. Social ecological systems framework (SES) variables selected for the empirical analysis.

\begin{tabular}{|c|c|c|}
\hline \multicolumn{3}{|r|}{ Selection of SES Variables for the Case Study } \\
\hline First Tier & Second Tier & Characteristic in the Case Study \\
\hline \multirow{9}{*}{$\begin{array}{l}\text { Resource } \\
\text { System (RS) }\end{array}$} & \multirow{5}{*}{ RS1 Sector } & Groundwater affected by surplus nitrate levels \\
\hline & & Decoupling of arable land and livestock production \\
\hline & & Proximity to the ports \\
\hline & & Cluster benefits (abattoirs, processors close) \\
\hline & & Energy production with bioenergy plants \\
\hline & \multirow{3}{*}{$\begin{array}{l}\text { RS4 Human- } \\
\text { constructed } \\
\text { facilities }\end{array}$} & $\begin{array}{l}\text { RS2 Clarity of system boundaries } \\
\quad \text { RS3 Size of resource system }\end{array}$ \\
\hline & & $\begin{array}{l}\text { Large number of livestock keeping facilities, intensive farming in } \\
\text { indoor housing systems, high regional density }\end{array}$ \\
\hline & & Installation of biogas plants from 2000 onwards \\
\hline & \multirow{3}{*}{$\begin{array}{l}\text { RU1 Resource } \\
\text { unit mobility }\end{array}$} & $\begin{array}{c}\text { RS5 Productivity of the system } \\
\text { RS6 Equilibrium properties } \\
\text { RS7 Predictability of system dynamics } \\
\text { RS8 Storage characteristics } \\
\text { RS9 Location }\end{array}$ \\
\hline \multirow{17}{*}{$\begin{array}{l}\text { Resource } \\
\text { Units (RU) }\end{array}$} & & Livestock facilities and animals hardly movable \\
\hline & & Water highly mobile \\
\hline & \multirow{10}{*}{$\begin{array}{l}\text { RU3 Interaction } \\
\text { among resource } \\
\text { units }\end{array}$} & RU2 Growth or replacement rate \\
\hline & & Pressure on water and soil resources, particularly handling of manure \\
\hline & & $\begin{array}{l}\text { Impossibility of closing natural loops, therefore large amounts of } \\
\text { manure applied to the fields for a long time }\end{array}$ \\
\hline & & Nutrient requirement varies depending on soil, weather, yields \\
\hline & & $\begin{array}{l}\text { Standardized calculation of amount of manure or mineralized fertilizers } \\
\text { applied to fields is difficult }\end{array}$ \\
\hline & & Traceability of pollutions sources due to groundwater mobility difficult \\
\hline & & Interactions between resources not considered sufficiently in the past \\
\hline & & Input of manure or crops to biogas plants \\
\hline & & $\begin{array}{l}\text { Increased competition for land following the installation of } \\
\text { biogas plants }\end{array}$ \\
\hline & & Application of fermentation residues to land \\
\hline & \multirow{4}{*}{$\begin{array}{l}\text { RU4 Economic } \\
\text { value }\end{array}$} & Intensification and specialization, rising number of animals \\
\hline & & Export orientation \\
\hline & & Competition for land \\
\hline & & High dependence of the region on the livestock sector \\
\hline & & $\begin{array}{c}\text { RU5 Number of units } \\
\text { RU6 Distinctive markings } \\
\text { RU7 Spatial and temporal distribution }\end{array}$ \\
\hline
\end{tabular}


Table 1. Cont

\begin{tabular}{|c|c|c|}
\hline \multicolumn{3}{|r|}{ Selection of SES Variables for the Case Study } \\
\hline First Tier & Second Tier & Characteristic in the Case Study \\
\hline \multirow{13}{*}{ Users (U) } & \multirow{4}{*}{$\begin{array}{l}\text { U3 History } \\
\text { of use }\end{array}$} & \multirow{2}{*}{$\begin{array}{c}\text { U1 Number of users } \\
\text { U2 Socioeconomic attributes of users }\end{array}$} \\
\hline & & \\
\hline & & Farmers encouraged by government to grow \\
\hline & & $\begin{array}{l}\text { Path dependencies created by long amortisation periods for stables and } \\
\text { establishment of clusters }\end{array}$ \\
\hline & & U4 Location \\
\hline & & U5 Leadership/entrepreneurship \\
\hline & & U6 Norms/social capital \\
\hline & & U7 Knowledge of SES/mental models \\
\hline & \multirow{3}{*}{$\begin{array}{l}\text { U8 Importance } \\
\text { of Resource }\end{array}$} & Farmers operate on the local level; manure is a regional problem. \\
\hline & & Regional concomitants (e.g., manure) are not considered by retailers \\
\hline & & Introduction of animal welfare labels as a chance to keep less animals if \\
\hline & \multirow{2}{*}{\multicolumn{2}{|c|}{ U9 Technology used }} \\
\hline & & \\
\hline \multirow{15}{*}{$\begin{array}{l}\text { Governance } \\
\text { Systems }\end{array}$} & \multirow{3}{*}{$\begin{array}{l}\text { GS1 } \\
\text { Government } \\
\text { organizations }\end{array}$} & $\begin{array}{l}\text { Institutional division of ministries (Food-Agriculture, } \\
\text { Water-Environment, Energy_Economy) }\end{array}$ \\
\hline & & $\begin{array}{c}\text { Party political differences influence work of ministries, } \\
\text { coalition governments }\end{array}$ \\
\hline & & $\begin{array}{c}\text { Different goals of actors within the agricultural system and within the } \\
\text { energy and the water system }\end{array}$ \\
\hline & \multirow{5}{*}{\multicolumn{2}{|c|}{$\begin{array}{l}\text { GS2 Nongovernment organizations } \\
\text { GS3 Network structures } \\
\text { GS4 Property-rights systems } \\
\text { GS5 Operational rules } \\
\text { GS6 Collective-choice rules }\end{array}$}} \\
\hline & & \\
\hline & & \\
\hline & & \\
\hline & & \\
\hline & \multirow{5}{*}{$\begin{array}{c}\text { GS7 } \\
\text { Constitutional } \\
\text { choice rules }\end{array}$} & $\begin{array}{l}\text { Fertilizer as implementation of the EU Water Framework Directive } \\
\text { (WFD) was executed by the ministry of agriculture, the ministry used } \\
\text { implementation leeway in favour of original agricultural goals. } \\
\text { Prioritization of food over water interests in the original version of the } \\
\text { fertilizer ordinance of } 1996 .\end{array}$ \\
\hline & & $\begin{array}{l}\text { Fertilizer ordinance as most important policy for steering nutrient } \\
\text { inputs in water and soil }\end{array}$ \\
\hline & & $\begin{array}{l}\text { Fermentation residues not considered in original fertilizer ordinance as } \\
\text { a problem }\end{array}$ \\
\hline & & $\begin{array}{l}\text { Ecological context such as weather insufficiently considered in the } \\
\text { fertilizer ordinance }\end{array}$ \\
\hline & & $\begin{array}{l}\text { Revision of fertilizer ordinance in } 2017 \text { (inclusion of } \\
\text { fermentation residues) }\end{array}$ \\
\hline & \multirow{2}{*}{$\begin{array}{l}\text { GS8 Monitoring } \\
\text { and sanctioning }\end{array}$} & $\begin{array}{l}\text { Problems with control and enforcement of fertilizer ordinance, } \\
\text { pollution sources partly difficult to identify }\end{array}$ \\
\hline & & $\begin{array}{l}\text { New fertilizer ordinance results in a major surplus of manure which } \\
\text { leads to partly illegal spreading }\end{array}$ \\
\hline
\end{tabular}


Table 1. Cont.

\section{Selection of SES Variables for the Case Study}

\begin{tabular}{|c|c|c|}
\hline First Tier & Second Tier & Characteristic in the Case Study \\
\hline \multirow{7}{*}{ Interactions } & & $\begin{array}{l}\text { I1 Harvesting levels of diverse users } \\
\text { I2 Information sharing among users } \\
\text { I3 Deliberation processes } \\
\text { I4 Conflicts among users } \\
\text { I5 Investment activities }\end{array}$ \\
\hline & \multirow{4}{*}{$\begin{array}{l}\text { I6 Lobbying } \\
\text { activities }\end{array}$} & $\begin{array}{l}\text { Lobbying by farmers organizations impeded inclusion of fermentation } \\
\text { residues into fertilizer ordinance }\end{array}$ \\
\hline & & $\begin{array}{l}\text { No consent from other federal states in Bundesrat for tightening of } \\
\text { fertilizer ordinance, burden for farmers in other states with no } \\
\text { over-fertilization }\end{array}$ \\
\hline & & $\begin{array}{l}\text { Even in new fertilizer ordinance agrarian interests dominate } \\
\text { water interests }\end{array}$ \\
\hline & & Water suppliers filed a complaint at the European level \\
\hline & $\begin{array}{l}\text { I7 } \\
\text { Self-organizing } \\
\text { activities }\end{array}$ & Trading of manure across regions \\
\hline & & I8 Networking activities \\
\hline \multirow{8}{*}{ Outcomes } & \multirow{2}{*}{$\begin{array}{l}\text { O1 Social } \\
\text { performance } \\
\text { measures }\end{array}$} & $\begin{array}{l}\text { Harsh economic losses particularly for small and family-owned farms } \\
\text { since new fertilizer ordinance }\end{array}$ \\
\hline & & Structural transformation in the region is accelerated \\
\hline & \multirow{5}{*}{$\begin{array}{l}\mathrm{O} 2 \text { Ecological } \\
\text { performance } \\
\text { measures }\end{array}$} & $\begin{array}{l}\text { Adding of surplus nutrients to the fields as a consequence of the } \\
\text { non-consideration of fermentation residues }\end{array}$ \\
\hline & & Interrelations of biogas with water and agriculture were underestimated \\
\hline & & $\begin{array}{l}\text { Local policymakers in Vechta early on recognized the pressure on land } \\
\text { and water resources, therefore less plants than in Cloppenburg }\end{array}$ \\
\hline & & $\begin{array}{l}\text { Scope of local policymakers to prevent installation of biogas plants was } \\
\text { limited, because the plants were privileged by national law }\end{array}$ \\
\hline & & $\begin{array}{l}\text { Few years after installation of biogas plants water suppliers identified } \\
\text { biogas plants as major cause of water pollution, they approached local, } \\
\text { federal and national policymakers but were not heard }\end{array}$ \\
\hline & \multirow{5}{*}{$\begin{array}{l}\text { ECO3 Flows } \\
\text { into and out of } \\
\text { focal SES }\end{array}$} & O3 Externalities to other SESs \\
\hline \multirow{4}{*}{$\begin{array}{l}\text { Related } \\
\text { Ecosystems }\end{array}$} & & $\begin{array}{l}\text { ECO1 Climate patterns } \\
\text { ECO2 Pollution patterns }\end{array}$ \\
\hline & & $\begin{array}{l}\text { Transportation of manure to other regions, storage capacities in the } \\
\text { regions exhausted }\end{array}$ \\
\hline & & $\begin{array}{l}\text { But: farmers in other regions prefer artificial fertilizer because of the } \\
\text { complex documentation process for manure }\end{array}$ \\
\hline & & Sharp price increase for selling manure \\
\hline
\end{tabular}

Source: own compilation based on Ostrom combined with the results [12]. 
Table 2. List of interview partners.

\begin{tabular}{cc}
\hline Interview Partner & Date, Location, Duration (in Hours) \\
\hline Representatives from the local administration (two actors) & 20 June 2018, Cloppenburg, 1:20 \\
Political actor & 1 June 2018, Vechta, 1:06 \\
General manager of the regional water board & 20 June 2018, Brake, 1:32 \\
Representative of the regional farmers' association & 31 May 2018, Vechta, 1:57 \\
Representative of the regional farmers' association & 31 May 2018, region Cloppenburg, 1:53 \\
General Manager of a regional animal food manufacturer & 21 June 2018, region Cloppenburg, 1:21 \\
Owner of a company for transportation of manure & 31 May 2018, Vechta, 1:37 \\
\hline
\end{tabular}

Source: own compilation.

\section{Unsustainable Water Governance in Regions with Intensive Livestock Farming in Germany}

According to the European Water Framework Directive (WFD) adopted in 2000, member states have to monitor water resources and if necessary, have to adopt measures for eliminating pollution $[32,38,39]$. An important element of the WFD is the Nitrates Directive, which was already introduced in 1991 aiming at preventing nitrates from agricultural sources [40]. Though nitrates are indispensable nutrients for plant growth and therefore commonly used in crop production, exceeded levels of nitrate entries may cause eutrophication, a deterioration of water quality and a loss of biodiversity [16]. In Germany already the first inventory in 2005 showed that a good status of groundwater would be difficult to achieve in some regions. Excessive nitrate levels were identified as the major challenge to water quality [39,41,42]. Accordingly, problems regarding the implementation of the WFD in Germany were known shortly after the WFD came into effect. However, water quality did not improve significantly in the years after. On the contrary, in some regions nitrate entries in water resources even increased [8]. These developments finally resulted in the claim of the European Commission against Germany before the European Court of Justice in 2016 [4]. On 21 June 2018, the Court judged that Germany was guilty of the violation of contracts with not complying with the WFD [1]. The infringement procedure is an expression of the partially unsustainable management of water resources. Data of the Federal Environmental Agency show that this holds especially true for regions with intensive agriculture and in particular with livestock farming [43]. The German Environmental Agency identifies agricultural activities and the use of manure as the main cause of nitrate entries into groundwater. Among the regions with the highest levels of nitrate is the western part of the federal state of Lower Saxony, where the agrarian sector has grown to be the second biggest economic branch [44]. Exceeded nitrate concentrations specifically stand out in the districts Cloppenburg and Vechta, these regions likewise count with the highest number of livestock units within Germany (see Figure 2). Next to the spreading of manure there are other sources of nitrate surplus, in particular household and industrial sewage. Nonetheless, the German Environmental Agency identifies agricultural activities as the primary source of nitrate inputs. Depending on the region causes are the excess use of mineral fertilizers or of manure [42]. The high number of animals in the region has been achieved by means of intensification and specialization. Particularly poultry and pig farming are highly modernized and produce for the national and the international market [2,45]. Thereby, during the past 20 years an internationally successful livestock industry has developed in the region, which has generated jobs and economic growth. In Figure 2 the regional concentration of livestock units in Germany is contrasted with the concentration of nitrates in water resources. The maps illustrate that nitrate levels are especially high in areas with a high density of farmed animals and therewith a high amount of manure. 


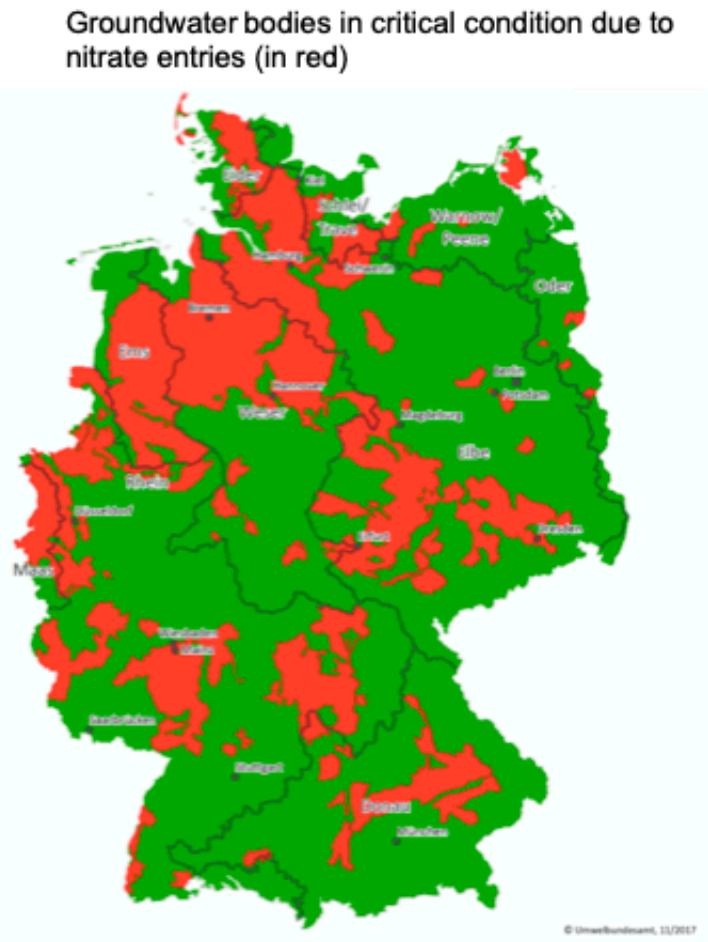

Source: Umweltbundesamt
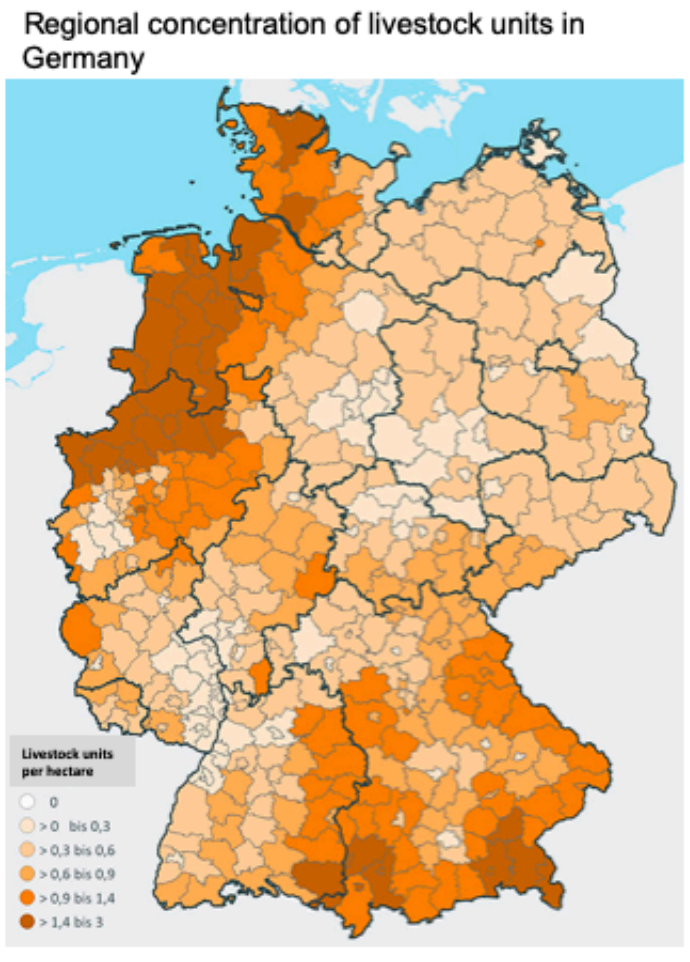

Source: Thünen-Institut/Statistisches Bundesamt

Figure 2. Nitrate entries in groundwater bodies compared to the regional concentration of livestock units in Germany. Sources: Umweltbundesamt, Thünen Institut [46,47].

Several scientific studies and government reports have been published over the past years that problematized the intense pressure on water resources by agricultural activities in the region $[8,41,48]$. Given this knowledge and the existing thresholds specified by the WFD, the question arises as to why water resources continued to worsen until the point of the intervention of the EU claim in 2016. This is particularly interesting due to the persistency of the problem of nitrate entries into groundwater and surface water in the regions Cloppenburg and Vechta for at least 20 years. Our starting point is a highly problematic outcome on the ecological scale, existing observations point towards an overharvesting of water and soil resources [42]. We systematically identify the developments, which led to these negative outcomes and thereby aim at understanding why the system is managed in an ecologically unsustainable way by using the SES. We hypothesize that a deficient consideration of the interplay of resources and varying goals of actors in the respective sectors contribute to the observed unsustainable governance solution.

\section{Water-Energy-Food Nexus in the Cloppenburg-Vechta Region}

This section presents the results of the empirical analysis and is primarily based on our fieldwork in the region. It is structured along the selected variables from the SES (see Table 1). We begin with the identification and discussion of the characteristics of the resource systems (RS), the resource units (RU), and the users $(\mathrm{U})$. Systematically analyzing the resource systems, the resource units and the users by using the proposed SES variables as guidance, will help us to understand the case and uncover the existing challenges. Ensuing, we analyze the governance systems (GS) to explore how and if the governing structures fit with the given ecological, economic and social context and if the nexus is considered in policymaking. 


\subsection{Resource Systems, Resource Units and Users}

In the social-ecological system under analysis we originally thought of a water-food nexus in terms of the resource system. Whilst the majority of existing SES studies would consider only one resource, we explicitly focus on the interplay of the water and the food sector (RS1 sector). The agricultural sector including upstream and downstream production stages is the dominant economic branch in the districts of Cloppenburg and Vechta [44]. The region's natural conditions for agricultural production are rather poor with comparatively unfertile soils that require greater efforts to generate yields than those in other regions in Germany. Given this disadvantage for crop production, farmers in the 1980s began to focus on livestock production and by means of intensification and specialization turned internationally competitive. The geographic proximity to the ports provided the advantage to import animal fodder under favorable conditions, which gradually led to the decoupling of arable land and livestock units [2]. Nowadays, the region has evolved into the hub of German livestock production including a strong export orientation. With an average of three livestock units per hectare the districts of Cloppenburg and Vechta count with the highest density of farmed animals in Germany. Main areas of production are laying hens, broiler and pig farming (RU resource units) [44]. The majority of these animals live in modern indoor housing systems, which allow for keeping a large number of animals on a small space. The establishment of abattoirs and processing plants in close proximity to the farms has generated cluster benefits on the one hand [2]. On the other hand, complex path dependencies have developed that make the region economically and socially highly dependent upon the livestock sector (RU4 economic value).

Besides the path dependencies created as a consequence of the formation of clusters, amortization periods for keeping systems are especially long in livestock farming [45] (U3 history of use). Stables are usually planned with an amortization period of 20 years [2]. Due to these path dependencies, the mobility of livestock units (RU1 resource unit mobility) within the social-ecological system is limited, because once established farming facilities are normally run for long periods. The structure of the sector and the way of keeping animals is partly a consequence of the need for farmers (U users) to compete on the international market. The representatives of farmers' associations who were interviewed for this research emphasized that farmers were in the past encouraged by government consultants to grow further and invest in additional housing systems to increase the number of animals and maximize productivity. For a long time, single-edged policies supported processes of intensification and the continued growth of farms. However, the success of the sector has partly been achieved at the expense of animal welfare and ecological sustainability [49].

In terms of environmental impacts, the decoupling of livestock and crop production has resulted in pressure on water and soil resources (RU3 interaction among resource units). Alongside animal welfare, the handling of manure was recognized as the pivotal challenge by all actors interviewed. The growing number of livestock units in the region resulted in the impossibility of closing natural loops on a regional scale. Several interviewees mentioned that as a consequence for many years large amounts of manure were applied to the fields (interviews 4 and 5). The amounts applied often exceeded the demands of the plants so that excess nutrients found their way into surface and groundwater and contributed to the pollution of these resources [43]. The degree of nutrient utilization of plants varies depending on soil structures, weather conditions and previous year's fertilization and yields (interviews 1, 2 and 3) (RU3 interaction among resource units). A standardized calculation of the amount of manure to be applied to a field is therefore difficult. A specific problem is the traceability of pollution sources due to the mobility of groundwater resources and the local distribution of official measurement points for water quality (RU1 resource unit mobility). The difficulty to identify the origins of excess nutrients in water resources was raised by several interviewees (interviews 2, 3 and 6). Interviewees 2 and 3 criticized the one-sided apportioning of blame towards farmers and the fading out of other pollution sources such as industrial and household sewages. Interviewee 5 instead assigned clear responsibility to farmers for the worsening groundwater quality due to over-fertilization (U users). Despite the disagreement regarding the exact contribution of the agricultural sector to 
water pollution, we observed a consensus among all interview partners that the complex interactions between livestock production, handling of manure, plant production and water quality have been insufficiently considered in the past (RU3 interactions among resource units).

During our fieldwork, a third important resource emerged as crucial for the sustainability in both the water and the food system (interviews 1-7): beginning in the year 2000, biogas plants were installed in the region as a consequence of the political promotion of renewable energies in Germany (RS4 human-constructed facilities). Bioenergy plays an increasingly important part in the development of renewable energy strategies in an increasing number of countries, despite its negative trade-offs with other resource systems, such as land use and water pollution [3,50]. The decisive impact of the installation of biogas plants was consensual among all interviewees. National policymakers were considering ways of replacing fossil energy with renewable alternatives to mitigate climate change. From this perspective, biogas plants were evaluated as a contribution to this. Therefore, increasing their share in the energy mix was regarded desirable. Their promotion was aspired in the Renewable Energy Act and instruments like feed-in tariffs were implemented [41]. Biogas plants were built across Germany between 2000 and 2014 and the second-highest number of plants is found in the state of Lower Saxony, accounting for almost one quarter of the nationwide production. Within Lower Saxony, $40 \%$ of biogas plants are located in regions with an emphasis on livestock production. Standing out is the district of Cloppenburg, with 118 plants compared to only 31 plants in the district of Vechta [51]. These biogas plants interact with the water and the food system in manifold ways: to produce energy, biogas plants are dependent upon the input of manure or crops, both resources stem from agricultural production (RU3 Interaction among resource units). In Lower Saxony, 10\% of agricultural land is used for the production of energy crops, with almost $20 \%$ in the district of Cloppenburg [51]. Thereby, the building of biogas plants intensified the competition for land [3]. On the other hand, the use of manure in biogas plants may present an option for farmers for exploiting faeces from livestock production [41]. In both cases fermentation residues are produced that can be used as natural fertilizer in crop production. The application of these fermentation residues may, if not correctly dispensed, contribute to the pollution of water resources [3]. We are, therefore, confronted with a complex interplay between the sectors water, food and energy (RS1 Sector) constituting a water-energy-food nexus. Whereas groundwater and surface water are natural resources, food production-especially livestock stables in the regions of Cloppenburg and Vechta-and biogas plants present human-constructed facilities (RS4 human-constructed facilities) within the social-ecological system.

In sum, adding to the already high density of livestock units in the area that are often decoupled from land and the accompanying surplus of manure, biogas plants exerted additional pressure on the food and the water system alike. Several interviewees mentioned that the intensified competition for land led to a sharp increase in leasing prices, which in turn resulted in the imperative for farmers to improve cost structures (interviews 2, 3 and 5). Contrary to other branches, the market for animal products in Germany and the European Union is characterized by a very low degree of differentiation. This results in the price being the main purchasing criterion, whereas criteria such as animal welfare or ecological sustainability still play a minor role [52,53]. Particularly in pig farming differentiation is extremely low and the market is highly internationalized [45]. The market for animal products in Germany is dominated by a handful of retailers that are organized on the national or even on the international level, whilst the majority of farmers still operate on the regional level (Interview 3) (U users). Concomitants of animal production such as the management of manure are normally limited to the local level and thus not considered in the behavior of retailers. The farmers we interviewed told us that the chance to obtain price premiums, especially in pig production, is barely existent. Therefore, the only opportunity for pig farmers to handle higher leasing prices was further intensification and scaling up (U3 history of use and U8 importance of resource). They argued that livestock production is characterized by market mechanisms that often force production methods on farmers that contradict ecological or animal welfare goals. As a consequence, the pressure on land use created by the construction of biogas plants contributed to an even higher number of animals in the 
region and therewith, higher amounts of manure to be handled (RU3 Interaction among resource units). The increased pressure on water and soil resources presents a local challenge that has to be dealt with by regional actors such as the water board (ECO2 ecological performance measures). Several interviewees stressed the problematic connection between the production of animal products for a price-sensitive national and international market and the regional limitation of negative accompanying symptoms (interviews 2 and 3). One opportunity to bypass the focus on pricing raised by three interviewees is the recent introduction of retail initiatives and labels for improved animal welfare $[45,53,54]$ (interviews 2,3 and 4). These private sector initiatives aim at achieving a differentiation of animal products for customers. A commonly applied criterion is more space allowance for the individual animal $[53,55]$. Farmers who participate in such schemes receive a financial compensation for keeping a reduced number of animals in their stables. Interviewee 3 argued that many farmers were willing to participate in such initiatives if the compensations were sufficient. He said that if these developments would catch on, the density of livestock units per hectare would decrease in the region and ease the pressure on water and soil resources. However, they likewise stated that the currently existing retail initiatives and criteria are not satisfactorily elaborated and that the financial means are insufficient to provide an economic advantage for a larger number of farmers. This results in a limited dissemination.

\subsection{Governance Systems and Interactions}

In the previous section, we elaborated on the complex interrelations within the water-energy-food nexus in the region under analysis. Our central assumption is that these interdependencies are insufficiently considered in the existing governance structures and thereby contribute to the unsustainable ecological outcomes in terms of the overharvesting of water resources ( $\mathrm{O} 2$ ecological performance measures). Due to the mutual dependence on each other, the sectors food, water and energy should ideally be closely intertwined. Water is needed for food production, manure applied to crop production negatively affects groundwater and surface water quality, energy plants compete for land with livestock and crop production and fermentation residues spread on agricultural soils also impair water resources. This intertwining should be reflected in interactions between interactions and governance systems to attain sustainable outcomes in the three sectors coequally.

In the first place, there is an institutional division between the sectors food, water, and energy in Germany reflected in the formal allocation of competences to the national ministries (GS1 government organizations). Food is assigned to the ministry of agriculture, water to the Ministry of Environment and Energy to the Ministry of Economy. The particularity of the German political system, with coalition governments being the general norm, results in the allocation of ministries between the coalition parties. Currently, the Ministry of Agriculture and the Ministry of Economy are headed by the Christian Democrats (CDU), whereas the Ministry of Environment is headed by the Social Democrats (SPD). Since 2005, the Ministry of Agriculture has been headed by either the CDU or their Bavarian sister party CSU, especially the CSU has a traditionally close affiliation to farmers and to traditional agricultural goals [56]. Though the general lines of policymaking are agreed upon in the coalition contracts at the beginning of the legislative period [57], topical differences between the parties are reflected in the work of the ministries. A prominent example was the disagreement between the former CSU minister of agriculture Schmidt and the former SPD minister of environment Hendricks regarding the use of the pesticide glyphosate in agriculture that escalated up to the European level.

The traditional ideational framework around agricultural policy can be labeled as "exceptionalism" and assumes that agricultural policy is different to other economic sectors and therefore requires special state involvement [58-60]. These ideas include traditional goals related to food security and income security for farmers, compared to more recent ideas emphasizing environmental sustainability or climate change [30,61-63]. These lines manifest in the work of the ministry of agriculture as well as on the European level within the Common Agricultural Policy (CAP). Although direct income payments for farmers are now partially coupled to agri-environmental measures and although the CAP has integrated sustainability concerns in the past decades [64], the share of environmental requirements 
within the CAP remains fairly limited [28]. In Germany, these priorities are apparent in the allocation of the ministry's budget, $65 \%$ of financial means are reserved for agrarian social policy [65].

The protection of water resources, the provision with safe drinking water and the protection of soils is within the responsibility of the Ministry of Environment, on the European as well as on the German level. However, important legal acts to achieve the targets set by the WFD, namely the fertilizer ordinance, were executed by the respective ministries of agriculture in Germany, on the national and on the federal levels [5,39]. The fertilizer ordinance can be considered the most important policy for steering nutrient inputs of agriculture into soil and water resources (interviews 1-7). It regulates the distribution and use of fertilizers in crop production and specifies thresholds for the application [39]. The original fertilizer ordinance was passed in 1996, a revised version in 2017 (GS7 constitutional choice rules). Interviewee 5 identified the institutional allocation in the Ministry of Agriculture as a pivotal challenge to the pollution of water resources in agrarian regions. In his view the ministry used the leeway in integrating demands from the WFD in favor of original agricultural goals and subordinated environmental goals. According to this, the original fertilizer ordinance was designed in a way that prioritized food sector interests over water sector interests and as a consequence did not contribute significantly to the decrease of nitrate inputs into water. This perspective was called into question by interviewees 2 and 3. Nonetheless, all interview partners emphasized that the original fertilizer ordinance (not including the revision in 2017) had one pivotal problem: fermentation residues from biogas plants were not considered in the registration of added fertilizers in this policy at all. Though when the fertilizer ordinance was first passed in 1996 biogas plants were virtually inexistent, it comes as a surprise that the rapid expansion of biogas plants from the year 2000 onwards [51] was not integrated in the fertilizer ordinance. As a consequence, until 2017 fermentation residues were applied to the fields in addition to the maximum allowable thresholds achieved with other fertilizers such as manure. In many cases this regulatory gap resulted in an over-fertilization of plants and soils and therewith in surplus nutrient inputs into water resources [3] ( $\mathrm{O} 2$ ecological performance measures). As a result, the thresholds for water pollution specified by the WFD, especially nitrate inputs, were exceeded continuously in the region under analysis [6,8,42]. One of the interviewees literally said that "the promotion of biogas plants was climate saving at the expense of groundwater resources" (Interview 5, translation by the authors).

The non-inclusion of fermentation residues in the fertilizer ordinance is puzzling and the interviews with the experts did not provide an unambiguous explanation. Several interview partners argued that policymakers were unaware of the complex ecological as well as economic interdependencies and of the impact the installation of biogas plants would have on the food and the water system in the region (Interviews 4 and 6). Indeed, the government promotion of biogas plants was passed by the ministry of economy and energy with the aim to increase the share of renewable energies in Germany. The renewable energy act (EEG) passed in 2000 created attractive conditions to build biogas plants by establishing a government-guaranteed feed-in tariff (GS7 Constitutional choice rules). Coupled with the then low agrarian price levels, many farmers opted for installing plants on their grounds [51]. Even the representative from the water board admitted that the interrelations with water and agriculture were underestimated at the beginning and that singular critical voices were not given sufficient attention. On the contrary, policymakers saw the chance to combine the promotion of renewable energies with another income pillar for farmers. Despite the national character of the fertilizer ordinance and the renewable energy act, regional differences in the distribution of biogas plants have emerged between the two administrative districts under analysis, with almost four-times the number of plants in Cloppenburg compared to Vechta [49]. Following one interviewee the significantly lower number in Vechta is because policymakers in Vechta early on recognized the pressure on land prices and on water resources accompanying the building of biogas plants (interview 6). Therefore, local policymakers used their legal competences regarding building permits to prevent the building of a higher number of plants. One representative from the political sphere on the contrary 
said that their scope of action was limited because the building of biogas plants was privileged by national law and thereby commanded top-down (interview 6).

Interview partner 5 reported that a few years after the biogas plants were built, water suppliers and other actors identified the policy gap as a central problem for the deteriorating water quality. As a consequence, they approached local, federal and finally national policymakers to achieve a revision of the fertilizer ordinance that included fermentation residues in the calculation of thresholds. The reasons why the water suppliers were not heard are controversial among the interviewees. Interviewee 5 believed that the inclusion of fermentation residues into the fertilizer ordinance was impeded by means of intense lobbying activities from agrarian associations. In contrast, representatives from the local administration highlighted another problem that is related to the peculiarities of German federalism (GS1 Government organizations). Following them, local authorities approached the federal government, which then approached the national government to achieve the inclusion of fermentation residues within the fertilizer ordinance. Since the fertilizer ordinance is a national policy with federal implementation, consent from the other federal states is necessary to change the policy. However, other federal states did not encounter the simultaneous challenge of high amounts of manure from intensive landless livestock production and high amounts of fermentation residues. At the same time, an update of the fertilizer ordinance would have resulted in additional documentation obligations and therewith in a burden for farmers and biogas producers in all federal states limiting the willingness of some of them to approve stricter legislation (Interview 6). Summing up, despite worsening water quality, the water suppliers were unsuccessful in their efforts to convince national policymakers to revise the fertilizer ordinance and thereby improve the protection of water resources from excessive nutrient inputs. Interviewee 5 reported that as a consequence of the failure to achieve policy change on the national level, the water suppliers decided to take the issue to the next level, namely the European Union. The measurement data showed that Germany did not comply with the thresholds defined by the European Water Framework Directive in several regions, among them the districts of Cloppenburg and Vechta. The claim was taken up by the media and by opposition political parties such as the Greens and it was instrumentalised to call into question the existing model of intensive agriculture and the ecological impact particularly of modern livestock farming (interactions). In 2013 the European Commission initiated an infringement procedure and referred Germany to the Court of Justice of the EU in 2016 for failing to address continuing water pollution by nitrates [4] (GS8 monitoring and sanctioning processes). For the agrarian subsystem in Germany, the claim and the ensuing public discussion thereby functioned as an external shock with the potential to initiate radical policy change.

The most fundamental policy change was the revision of the fertilizer ordinance that was passed in 2017 [5] (GS7 constitutional choice rules). The impact of the new fertilizer ordinance on the food, the water and the energy system was consensually recognized by all interview partners, in particular regarding the consideration of fermentation residues in the calculation of fertilizers. In addition, the new policy specifies new thresholds and documentation obligations. Notwithstanding, the evaluation of the policy varies considerably, among the interview partners as well as among policymakers and scientists. In a recently published expert report, the achievement of the water protection objectives is put in doubt with the argumentation that agrarian interests still prevail water interests (I6 lobbying activities) [6]. The critical assessment was supported by one interviewee, who explicitly referred to this expert report (interview 5). In his opinion, the major deficiency of the fertilizer ordinance is the lack of control of the application of fertilizers, given the limited control and sanctioning capacities of the responsible public authorities (GS8 monitoring and sanctioning processes). A contrary position on the evaluation of the fertilizer ordinance is adopted by farmers and by actors from the food processing chain. In our interviews, it became clear that they expected and already felt a severe impact of the new policy on the food sector in the region. The adapted thresholds of spreading manure combined with the new requirement to include fermentation residues in the calculation of the amount of fertilizers, result in a major surplus of manure. Combined with adverse weather conditions that hamper the application of manure as fertilizer to the fields, the surplus of manure has reached critical dimensions in the region. 
According to the interviewees 2 and 3, the varying ecological conditions are inadequately considered in the rigid guidelines of the fertilizer ordinance. If the manure cannot be applied to the fields, it has to be either stored or transported to other regions with a lack of natural manure (ECO3 flows into and out of focal SES). Storage capacities in the region are exhausted, which is why transportation is often the only viable option (interview 1).

Especially in the south-western regions of Lower Saxony, agriculture relies on crop production and on the purchase of either artificial fertilizers (mineral fertilizers) or on the import of manure from regions with high livestock production. In theory, the surplus could be transported to these regions. However, the new fertilizer ordinance obligates farmers receiving manure to fulfill detailed documentations. In addition, as soon as a farmer added manure to the fields, he took the risk to be sanctioned in case of even minor trespassing in case of wrong calculations. As a consequence, many crop-producing farmers opt for buying mineral fertilizers instead of applying manure, because the nutrient components of the former are precise and easily determined. The decreasing readiness of other agrarian regions to accept manure combined with the higher surplus of manure as a consequence of the new fertilizer ordinance resulted in a sharp price increase for the release of manure. Farmers now have to pay more than the double of the price they paid before the coming into force of the new fertilizer ordinance to "sell" their manure. The price increase for manure must then be allocated to the production price of the animal. However, due to highly internationalized markets for pigs and broiler the purchasing prices at abattoirs remain the same. Accordingly, the surplus of manure for many farmers leads to a large loss of revenue. According to one interviewee, the current return per fattening pig is around 5 Euros, if the return further decreases, production will become unfeasible (Interview 3). Following him, particularly family-owned farms with few lands encounter harsh economic losses since the new fertilizer is in place (O1 social performance measures). However, due to the path dependencies in livestock production, foremost the long amortization periods for stables make it almost impossible for farmers to simply pause production (U3 History of use). Above all, farmed animals are living creatures protected by the German animal welfare law [66]. Once an animal is born, it must be raised even if that means an economic loss for the farmer. Nonetheless, the representatives from the farmer's associations told us that the impact of the new fertilizer ordinance is already forcing farmers to stop raising animals. Due to the specialization in the sector, with piglet production being usually done in other farms than the fattening of the pigs, the giving up of one farmer often affects other farmers in the region or even in other regions. Several interviewees stressed that these economic challenges stemming from the new guidelines of the fertilizer ordinance are particularly affecting small and family-owned farms in the region, whilst larger farms are in funds to build larger storage capacities or pay the surcharges for the transportation of manure. Among all interview partners there was a consensus that a side effect of the new fertilizer ordinance will be an accelerated structural transformation in the region. The depicted developments are subsumed in Figure 3. 


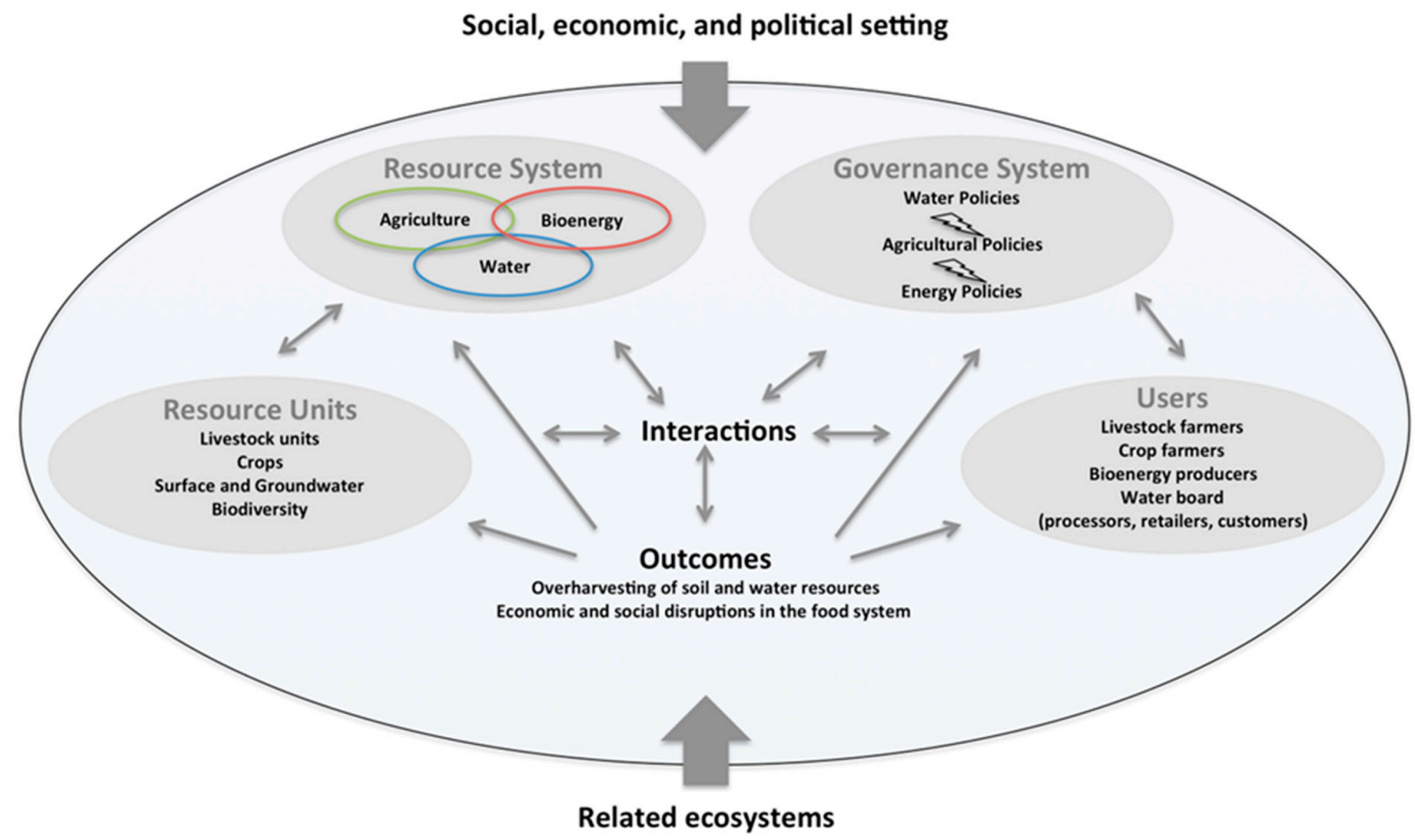

Figure 3. The social-ecological systems framework adapted for the Water-Energy-Food Nexus in the Cloppenburg and Vechta region. Source: own compilation based on Ostrom [12] and the results of the empirical analysis.

At this point in time it remains unclear to what degree policymakers were aware of the economic and finally social pressure (O1 social performance measures) induced by the revision of the fertilizer ordinance that originally aimed at improving ecological sustainability $(\mathrm{O} 2$ ecological performance measures). The interviewed actors agreed that significant changes are underway. One interviewee said that especially the coming two to three years would decide on the future alignment of the food sector in the region (interview 2). Interestingly, even livestock farmers argued that there was a need for a reduction in the number of livestock units in the region. They reported that most farmers were indeed willing to reduce the number of animals if there was an alternative way of compensating the economic losses. However, these options are somewhat unclear in the current competitive market for animal products that is steered by the price as main criterion. As a promising alternative, the current developments in animal welfare were raised that give the farmer the option to keep less animals on more space with financial compensation. Due to the immense pressure on the food system, local actors are currently seeking new forms of cooperation to find solutions for the handling of manure and fermentation residues (interviews 1, 2, 3 and 4). These include actors from the water, the food and the energy system to jointly find ways to increase ecological, economic and social sustainability and thereby consider the goals of the different systems coequally (I7 self-organizing activities).

\section{Discussion and Conclusions}

Applying the social-ecological systems framework, the case study has illustrated the complex interactions between the sectors water, energy, food and the related policies that are often designed without considering fit with the other sectors. A policy such as the promotion of renewable energies may have a positive effect on the energy mix and thus be positively evaluated from the energy perspective. However, it may at the same time provoke distortions in other policy fields. In the case at hand, the promotion of biogas plants resulted in the competition for land resources, which in turn resulted in the need to further intensify livestock and crop production. Ultimately, the surplus of fermentation residues from biogas plants-formally disregarded in the first place - and of manure from livestock production resulted in increased pressure on water resources and thus negatively affected the water system. Later on, in 2017, policymakers reacted to the challenge of water pollution with a policy 
that seems to contribute to structural changes in the agrarian system in the region under analysis. In 2019, the European Commission called on Germany to further tighten the regulations passed in 2017.

Our initial assumption regarding the missing consideration of the interplay between the resources water and food in resource governance can thus be confirmed. In addition, we showed that a third human-induced resource in the social-ecological system, the production of bioenergy, adds to the complexity of policymaking within and between the three systems. Our findings from the interviews illustrate that a major problem to achieve harmonized policies to foster sustainability in the three subsystems coequally is the divergence of policy goals that shape actors' behavior. Another problem is the high complexity of the ecological, social and economic interdependencies among the three systems that presents a challenge for policymakers. One of the interviewees used the metaphor of a spider web to describe the complex relationships between ecological, economic and social variables as well as the uncertainty: if one string is moved, everything else begins to move, however, it is not always foreseeable at which points the movements will take place (interview 3).

The analysis therefore calls for a more explicit consideration of the water-energy-food nexus in policymaking on the one hand and in the theoretical development of the social-ecological systems framework on the other hand. In Germany, particularities of the political system such as the division of responsibilities between ministries and the domination of party political interests in these ministries complicate the coequal consideration of the demands of the three systems. Notwithstanding, the analysis has shown that due to the mutual interdependence the non-consideration of the nexus may lead to unsustainable outcomes within all systems. This becomes particularly apparent in the food system that has for long ignored demands from the water system. Only when external pressure increased and endangered the food system's economic goals a stricter policy was passed with the new fertilizer ordinance. However, these externally induced changes now affect the pillars of a highly path-dependent food system in the region in a dramatic way. Earlier considerations of the complex interrelationships between food and water resources might have eased the situation. Moreover, the analysis has exemplified the difficulty of making one-size-fits-all policies on the European or on the national level. Depending on local ecological, economic and social structures, nationally uniform policies may have adverse or unintended outcomes on the local level.

Author Contributions: Conceptualization: C.S.V., M.M., N.C.B. and B.S.; Writing-original draft preparation: C.S.V. and M.M.; Writing—review and editing: M.M., N.C.B. and B.S.; Funding acquisition: N.C.B. and B.S.

Funding: The work was funded by MWK Lower Saxony Niedersächsisches Vorab as part of the collaborative project "metapolis-an inter and transdisciplinary research platform for the sustainable development of urban-rural relations', funded by the Federal State of Lower Saxony" (Grant No. ZN3121) as well as by the Federal Ministry of Education and Research (joint project "AgroEcological solutions for Safe and fair Operating Spaces of agricultural systems in the urban-rural transition zone-AgroEcoSOS" (Grant No. 031B0420). We acknowledge support by the German Research Foundation DFG and the Open Access Publication Funds of the Technische Universität Braunschweig.

Conflicts of Interest: The authors declare no conflict of interest.

\section{References}

1. European Commission v Federal Republic of Germany. Judgment of the Court (Ninth Chamber), European Commission v Federal Republic of Germany, Case C-543/16. 21 June 2018. Available online: https://eur-lex.europa.eu/legal-content/EN/TXT/?qid=1573031485756\&uri=CELEX:62016CA0543 (accessed on 6 November 2019).

2. BMEL. Wege zu einer gesellschaftlich akzeptierten Nutztierhaltung. Gutachten. Available online: http: //www.bmel.de/SharedDocs/Downloads/Ministerium/Beiraete/Agrarpolitik/GutachtenNutztierhaltung. pdf\%3F_blob\%3DpublicationFile (accessed on 5 November 2019).

3. Von Buttlar, C.; Willms, M. Bewertung des Energiepflanzenanbaus für Biogasanlagen vor dem Hintergrund der Anforderungen der Europäischen Wasserrahmenrichtlinie. Ber. Landwirtsch 2016, 94. [CrossRef] 
4. European Commission. Water: Commission Refers GERMANY to the Court of Justice of the EU over Water Pollution Caused by Nitrates, European Commission: Brussels. 2016. Available online: https://europa.eu/rapid/press-release_IP-16-1453_EN.htm (accessed on 5 November 2019).

5. BMJV. Verordnung über die Anwendung von Düngemitteln, Bodenhilfsstoffen, Kultursubstraten und Pflanzenhilfsmitteln nach den Grundsätzen der guten fachlichen Praxis beim Düngen. 2017. Available online: http://www.gesetze-im-internet.de/d_v_2017/index.html (accessed on 5 November 2019).

6. Taube, F. Expertise zur Bewertung des neuen Düngerechts (DüG, DüV, StoffBilV) von 2017 in Deutschland im Hinblick auf den Gewässerschutz. Studie im Auftrag von: BDEW-Bundesverband der Energie- und Wasserwirtschaft e. V. 2018. Available online: https://www.bdew.de/media/documents/ Expertise_Bewertung_D\%C3\%BCG_D\%C3\%BCV_StoffBilV_Taube_11.06.2018_oeffentlich.pdf (accessed on 6 November 2019).

7. European Commisson. July Infringements Package: Key Decisions, European Commission: Brussels. 2019. Available online: https://ec.europa.eu/commission/presscorner/detail/en/inf_19_4251 (accessed on 6 November 2019).

8. BMU; BMEL. Nitratbericht 2016. 2017. Available online: https://www.bmu.de/fileadmin/Daten_BMU/ Download_PDF/Binnengewaesser/nitratbericht_2016_bf.pdf (accessed on 5 November 2019).

9. Hellegers, P.; Zilberman, D.; Steduto, P.; McCornick, P. Interactions between water, energy, food and environment: Evolving perspectives and policy issues. Water Policy 2008, 10, 1-10. [CrossRef]

10. Hussey, K.; Pittock, J. The Energy-Water Nexus: Managing the Links between Energy and Water for a Sustainable Future. Ecol. Soc. 2012, 17. [CrossRef]

11. Ingold, K.; Fischer, M.; de Boer, C.; Molinga, P.P. Water management across borders, scales and sectors: Recent developments and future challenges in water policy analysis. Environ. Policy Gov. 2016, 26, $223-228$. [CrossRef]

12. Ostrom, E. A general framework for analyzing sustainability of social-ecological systems. Science 2009, 325, 419-422. [CrossRef]

13. Epstein, G.; Pittman, J.; Alexander, S.M.; Berdej, S.; Dyck, T.; Kreitmair, U.; Rathwell, K.J.; Villamayor-Tomas, S.; Vogt, J.; Armitage, D. Institutional Fit and the Sustainability of Social-Ecological Systems. Curr. Opin. Environ. Sustain. 2015, 14, 34-40. [CrossRef]

14. van Riper, C.J.; Thiel, A.; Penker, M.; Braito, M.; Landon, A.C.; Thomson, J.M.; Tucker, C.M. Incorporating multilevel values into the social-ecological systems framework. Ecol. Soc. 2018, 23, 25. [CrossRef]

15. Endo, A.; Tsurita, I.; Burnett, K.; Orencio, P.M. A review of the current state of research on the water, energy, and food nexus. J. Hydrol. Reg. Stud. 2017, 11, 20-30. [CrossRef]

16. Reddy, R.V.; Cunha, D.G.F.; Kurian, M. A Water-Energy-Food Nexus Perspective on the Challenge of Eutrophication. Water 2018, 10, 101. [CrossRef]

17. Möck, M.; Vogeler, C.S.; Bandelow, N.C.; Schröder, B. 2019 Layering Action Situations to Integrate Spatial Scales, Resource Linkages, and Change over Time: The Case of Groundwater Management in Agricultural Hubs in Germany. Policy Stud. J.. accepted for publication.

18. Ingold, K.; Moser, A.; Metz, F.; Herzog, L.; Bader, H.-P.; Scheidegger, R.; Stamm, C. Misfit between physical affectedness and regulatory embeddedness: The case of drinking water supply along the Rhine River. Glob. Environ. Chang. 2018, 48, 136-150. [CrossRef]

19. Metz, F.; Glaus, A. Integrated Water Resources Management and Policy Integration: Lessons from 169 Years of Flood Policies in Switzerland. Water 2019, 11, 1173. [CrossRef]

20. Ostrom, E. Background on the Institutional Analysis and Development Framework. Policy Stud. J. 2011, 39, 7-27. [CrossRef]

21. Ostrom, E.; Cox, M. Moving Beyond Panaceas: A Multi-Tiered Diagnostic Approach for Social-Ecological Analysis. Environ. Conserv. 2010, 37, 451-463. [CrossRef]

22. McGinnis, M.D.; Ostrom, E. Social-ecological system framework: Initial changes and continuing challenges. Ecol. Soc. 2014, 19. [CrossRef]

23. Schlager, E.; Cox, M. The IAD Framework and the SES Framework: An Introduction and Assessment of the Ostrom Workshop Frameworks. In Theories of the Policy Process, 4th ed.; Weible, C.M., Sabatier, P.A., Eds.; Westview Press: New York, NY, USA, 2017; pp. 212-252. 
24. Leslie, H.M.; Basurto, X.; Nenadovic, M.; Sievanen, L.; Cavanaugh, K.C.; Cota-Nieto, J.J.; Erisman, B.E.; Finkbeiner, E.; Hinojosa-Arango, G.; Moreno-Báez, M.; et al. Operationalizing the social-ecological systems framework to assess sustainability. Proc. Natl. Acad. Sci. USA 2015, 112, 5979-5984. [CrossRef]

25. Hinkel, J.; Cox, M.E.; Schlüter, M.; Binder, C.R.; Falk, T. A diagnostic procedure for applying the social-ecological systems framework in diverse cases. Ecol. Soc. 2015, 20, 32. [CrossRef]

26. Thiel, A.; Adamseged, M.E.; Baake, C. Evaluating an instrument for institutional crafting: How Ostrom's social-ecological systems framework is applied. Environ. Sci. Policy 2015, 53, 152-164. [CrossRef]

27. Lijphart, A. Patterns of Democracy-Government Forms and Performance in Thirty-Six Countries, 2nd ed.; Yale University Press: New Haven, CT, USA; London, UK, 2012.

28. Alons, G. Environmental policy integration in the EU's common agricultural policy: Greening or greenwashing? J. Eur. Public Policy 2017, 24, 1604-1622. [CrossRef]

29. Jordan, A.; Liefferink, D. The Europeanization of National Environmental Policy; Routledge: London, UK; New York, NY, USA, 2004.

30. Daugbjerg, C.; Farsund, A.A.; Langhelle, O. The resilience of paradigm mixes: Food security in a post-exceptionalist trade regime. J. Eur. Public Policy 2017, 1698-1715. [CrossRef]

31. Liebherr, E.; Ingold, K. Actors in Water Governance: Barriers and Bridges for Coordination. Water 2019, 11, 326. [CrossRef]

32. Kirschke, S.; Franke, C.; Newig, J.; Borchardt, D. Clusters of water governance problems and their effects on policy delivery. Policy Soc. 2019, 38, 255-277. [CrossRef]

33. Villamayor-Tomas, S.; Grundmann, P.; Epstein, G.; Evans, T.; Kimmich, C. The Water-Energy-Food Security Nexus through the Lenses of the Value Chain an the Institutional Analysis and Development Frameworks. Water Altern. 2015, 8, 735-755.

34. Klümper, F.; Theesfeld, I. The Land-Water-Food Nexus: Expanding the Social-Ecological System Framework to Link Land and Water Governance. Resources 2017, 6, 28. [CrossRef]

35. OOWV. Unsere Regionen; OOWV: Brake, Germany, 2018.

36. Landesamt für Statistik Niedersachsen. Bevölkerungsveränderungen der kreisfreien Städte und Landkreise. 2017. Available online: https://www.statistik.niedersachsen.de/themenbereiche/bevoelkerung/ themenbereich-bevoelkerung---tabellen-87673.html (accessed on 6 November 2019).

37. Bogner, A.; Littig, B.; Menz, W. Interviewing Experts; Palgrave Macmillan: London, UK, 2009. [CrossRef]

38. European Commission. The EU Water Framework Directive-Integrated River Basin Management for Europe, European Commission: Brussels. 2016. Available online: https://eur-lex.europa.eu/legal-content/ EN/TXT/?uri=CELEX:32000L0060 (accessed on 6 November 2019).

39. Arle, J.; Mohaupt, V.; Kirst, I. Monitoring of Surface Waters in Germany under the Water Framework Directive-A Review of Approaches, Methods and Results. Water 2016, 8, 217. [CrossRef]

40. Council of the European Communities. Council Directive 91/676/EEC of 12 December 1991 Concerning the Protection of Waters against Pollution Caused by Nitrates from Agricultural Sources. 1991. Available online: https:/eur-lex.europa.eu/legal-content/EN/ALL/?uri=CELEX\%3A31991L0676 (accessed on 6 November 2019).

41. Kastens, B.; Newig, J. The Water Framework Directive and Agricultural Nitrate Pollution: Will Great Expectations in Brussels be Dashed in Lower Saxony? Eur. Environ. 2007, 17, 231-246. [CrossRef]

42. Umweltbundesamt. Fakten zur Nitratbelastung in Grund- und Trinkwasser. Available online: https://www.umweltbundesamt.de/themen/fakten-zur-nitratbelastung-in-grund-trinkwasser (accessed on 5 November 2019).

43. Umweltbundesamt. Quantifizierung der landwirtschaftlich verursachten Kosten zur Sicherung der Trinkwasserbereitstellung; Umweltbundesamt: Dessau-Roßlau, Germany, 2017; Volume 43.

44. Niedersächsisches Ministerium für Ernährung, Landwirtschaft und Verbraucherschutz. Die Niedersächsische Landwirtschaft in Zahlen. 2017. Available online: https://www.ml.niedersachsen.de/download/124920/Die_ niedersaeschsische_Landwirtschaft_in_Zahlen_2017.pdf (accessed on 6 November 2019).

45. Vogeler, C.S. Farm Animal Welfare Policy in Comparative Perspective: Determinants of Cross-national Differences in Austria, Germany, and Switzerland. Eur. Policy Anal. 2017, 3, 20-47. [CrossRef]

46. Umweltbundesamt. FAQs zu Nitrat im Grund- und Trinkwasser. Available online: https://www. umweltbundesamt.de/faqs-zu-nitrat-im-grund-trinkwasser\#textpart-6; (accessed on 5 November 2019). 
47. Thünen-Institut, Statistisches Bundesamt. Nutztierhaltung und Fleischproduktion in Deutschland. 2010. Available online: https://www.thuenen.de/de/thema/nutztiershyhaltung-und-aquakultur/nutztierhaltungund-fleischproduktion-in-deutschland/ (accessed on 5 November 2019).

48. Sachverständigenrat für Umweltfragen. Stickstoff: Lösungsstrategien für ein drängendes Umweltproblem. Sondergutachten; Berlin. 2015. Available online: http://www.umweltrat.de/SharedDocs/Downloads/ DE/02_Sondergutachten/2012_2016/2015_01_SG_Stickstoff_HD.pdf?_blob=publicationFile (accessed on 6 November 2019).

49. Vogeler, C.S. Why do farm animal welfare regulations vary between EU member states? A comparative analysis of societal and party political determinants in France, Germany, Italy, Spain, and the UK. J. Common Mark. Stud. 2019, 57, 317-335. [CrossRef]

50. Hao, M.; Jiang, D.; Wang, J.; Fu, J.; Huang, Y. Could biofuel development stress China's water resources? GCB Bioenergy 2017, 9, 1447-1460. [CrossRef]

51. Kompetenzzentrum Niedersachsen Netzwerk Nachwachsenda Rohstoffe und Bioökonomie e.V. Biogas in Niedersachsen-Inventur 2016; Niedersächsisches Ministerium für Ernährung, Landwirtschaft und Verbraucherschutz: Hannover, Germany, 2017; Volume 7.

52. Grethe, H. The Economics of Farm Animal Welfare. Annu. Rev. Resour. Econ. 2017, 9, 75-94. [CrossRef]

53. Lundmark, F.; Berg, C.; Röcklinsberg, H. Private Animal Welfare Standards-Opportunities and Risks. Animals 2018, 8, 4. [CrossRef] [PubMed]

54. Vanhonacker, F.; Verbeke, W. Public and Consumer Policies for Higher Welfare Food Products: Challenges and Opportunities. J. Agric. Environ. Ethics 2014, 27, 153-171. [CrossRef]

55. Yeates, J.W. Naturalness and Animal Welfare. Animals 2018, 8, 53. [CrossRef] [PubMed]

56. Merz, N.; Regel, S. Die Programmatik der Parteien. In Handbuch Parteienforschung; Niedermayer, O., Ed.; Springer: Wiesbaden, Germany, 2013; pp. 211-238. [CrossRef]

57. Bandelow, N.C.; Eckert, F.; Rüsenberg, R. Wie Funktionieren Koalitionsverhandlungen in Der Gesundheitspolitik? Observer Gesundheit: Bonn, Germany, 2017.

58. Coleman, W.D.; Skogstad, G.D.; Atkinson, M.M. Paradigm Shifts and Policy Networks: Cumulative Change in Agriculture. J. Public Policy 1996, 16, 273. [CrossRef]

59. Grant, W. Is agricultural policy still exceptional? Political Q. 1995, 66, 156-169. [CrossRef]

60. Skogstad, G. Ideas, Paradigms and Institutions: Agricultural Exceptionalism in the European Union and the United States. Governance 1998, 11, 463-490. [CrossRef]

61. Daugbjerg, C.; Feindt, P.H. Post-exceptionalism in public policy: Transforming food and agricultural policy. J. Eur. Public Policy 2017, 24, 1565-1584. [CrossRef]

62. Greer, A. Post-exceptional politics in agriculture: An examination of the 2013 CAP reform. J. Eur. Public Policy 2017, 2, 1-19. [CrossRef]

63. Tosun, J. Party support for post-exceptionalism in agri-food politics and policy: Germany and the United Kingdom compared. J. Eur. Public Policy 2017, 1623-1640. [CrossRef]

64. Daugbjerg, C.; Swinbank, A. Three Decades of Policy Layering and Politically Sustainable Reform in the European Union's Agricultural Policy. Governance 2016, 29, 265-280. [CrossRef]

65. Bundesministerium für Ernährung und Landwirtschaft. Regierungsentwurf Haushalt 2018. Bundesministerium für Ernährung und Landwirtschaft. 2018. Available online: https://www.bmel. de/SharedDocs/Downloads/Presse/PM32-2018-HaushaltAnlage.pdf?_blob=publicationFile (accessed on 6 November 2019).

66. Hirt, A.; Maisack, C.; Moritz, J. Tierschutzgesetz: Mit TierSchHundeV, TierSchNutztV, TierSchVersV, TierSchTrV, EU-Tiertransport-VO, TierSchlV, EU-Tierschlacht-VO: Kommentar, 3rd ed.; Verlag Franz Vahlen: München, Germany, 2016; p. 1210.

(C) 2019 by the authors. Licensee MDPI, Basel, Switzerland. This article is an open access article distributed under the terms and conditions of the Creative Commons Attribution (CC BY) license (http://creativecommons.org/licenses/by/4.0/). 